\title{
STUDENTS OF MILITARY CLASSES CONCERNING SELECTED ASPECTS OF POLAND'S NATIONAL SECURITY. AN EMPIRICAL STUDY
}

\author{
Ilona URYCH, PhD \\ i.urych@akademia.mil.pl \\ Faculty of National Security \\ War Studies University, Warsaw, Poland
}

\begin{abstract}
This article examines the opinions of students of military classes concerning aspects of Poland's national security. The main problem of the study is contained in the following question: How do students of military classes describe selected conditions of Poland's national security? Thus, the objective of the article was to diagnose the opinions of students of military classes about national security in Poland. The study involved an analysis of the following aspects of Poland's national security in the opinion of participating students of military classes: social attitudes that are conducive to the strengthening of national security, factors affecting national identity, and threats to national security. An analysis of the results of the study also made it possible to determine the source of the respondents' knowledge about national security.

The article briefly looks at the origins of military classes and describes the research methodology, and then presents a diagnosis of the opinions of students of military classes about selected aspects of Poland's national security: social attitudes conducive to the strengthening of national security, factors shaping national identity, and threats to national security. The sources of the respondents' knowledge about national security are indicated too. In the conclusion, answers to the research problems were provided and the need for further studies of the matter in question was identified.
\end{abstract}

Keywords: national security, young people, military classes, uniformed classes, education for security

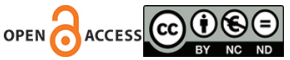




\section{Introduction}

In Poland, the term "military classes" is used to describe junior high school and secondary school classes whose curricula include broadly defined education for security, supplemented with topics related to national defence, the history of the Polish military, and the shaping of patriotic attitudes among children and young people. Moreover, military classes enjoy great and increasing popularity. At present, the number of students of military classes is approximately 50 thousand (Glińska 2017). It must be indicated that the repertoire of their objectives, curricula, and content is huge: from superficial fascination for the military to the amazing involvement of the teachers, the support of the educational authorities and the local community, which makes it possible to establish curricula that are attractive from the essential and pragmatic standpoint. Therefore, there are uniformed schools and classes with enthusiasts, theoreticians, and practitioners: both teachers and students, whose work integrates with the local community and shapes patriotic, civic, and pro-social attitudes (cf. Urych 2016; Skrabacz, Urych and Kanarski 2016; Kanarski, Koter and Urych 2014).

In the light of the need for empirical studies on the functioning of military classes, the Chair of Education for Security of the War Studies University conducts studies on the problem of military classes in secondary schools. This document presents part of the recently completed pilot study ${ }^{1}$ and describes the knowledge that students of military classes have about selected aspects of national security.

The article briefly looks at the origins of military classes and describes the research methodology, and then presents a diagnosis of the opinions of students of military classes about selected aspects of Poland's national security: social attitudes conducive to the strengthening of national security, factors shaping national identity, and threats to national security. The sources of the respondents' knowledge about national security are also indicated. In the conclusion, answers to the research problems were provided and the need for further studies of the matter in question was identified.

1 The study was conducted on a group of 200 randomly selected students of military classes in January and February 2017. 


\section{Research methodology}

The object of the study was the opinions of students of military classes about selected aspects of national security in Poland. The objective of the study was to determine the opinions of students of military classes about the aspects of national security in Poland, with a particular focus on social attitudes conducive to the strengthening of national security, factors shaping national identity, and threats to national security. Another objective of the study was a diagnosis of the knowledge of the respondents about national security.

The main problem of the study was contained in the following question: How do students of military classes describe selected conditions of Poland's national security? In connection with the main problem, the following detailed questions were formulated:

1. What social attitudes are conducive to the strengthening of national security in the opinion of the participating students of military classes?

2. What factors shape national identity in the opinion of the participating students of military classes?

3. What are the threats to national security in the opinion of the participating students of military classes?

4. Where do the respondents get their knowledge about national security?

In the study, the diagnostic survey method (Pilch and Bauman 2001, pp. 79-82), the poll technique, and the questionnaire research tool were used. The independent variable of gender, with two indicators: woman and man, was used. The study was conducted in January and February 2017.

The study was a pilot, trial study (cf. Jakubowska 1993, p. 112; Sztumski 1999, p. 40) because it assumed, among other things, preliminary analysis of results so as to obtain information about certain trends and directions of dependencies that were the object of the study, to refine the knowledge of the investigator about the environment to undergo a systematic study, to check the suitability of the prepared research tool, including the correctness of the selection of the questions, 
the scope of the studied problem, and the messages and instructions used in the tools. Due to the nature of the study, the group of students of military classes of secondary schools was fairly small and had only 200 members. The sample was selected randomly, assuming that the studied schools were randomly selected from among secondary schools that have the so-called military profile classes, which have signed cooperation agreements with the War Studies University in Warsaw. An analysis of the results of the study indicates that $54.5 \%$ of the respondents were men and $45.5 \%$ were women. The structure of the study group according to gender is shown in Fig. 1.

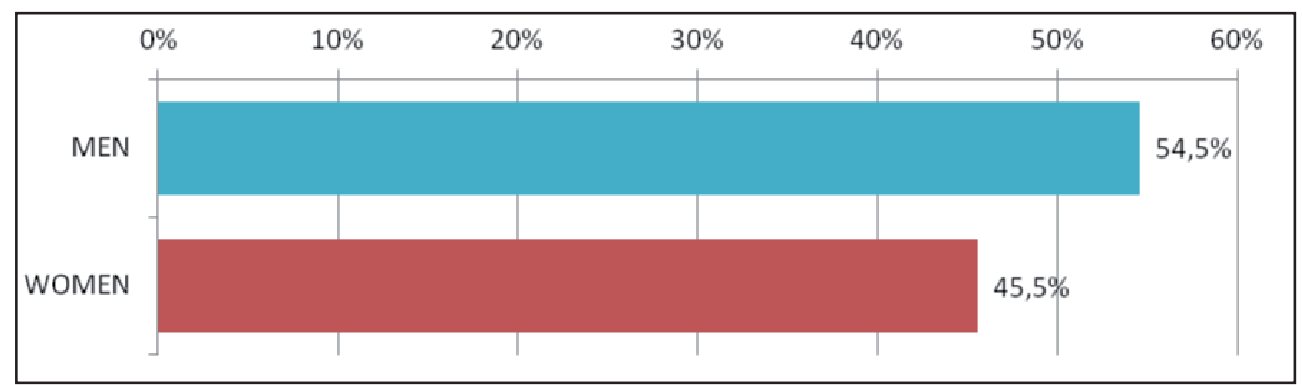

Fig. 1. Structure of the study group according to gender

The study also made it possible to identify students of military classes in relation to military traditions in their families. Based on the analysis of the results of the research, it can be stated that military traditions were maintained in the families of $62 \%$ of the respondents. Almost one in three respondents had an uncle (29.9\%) or a grandfather (28.5) who serves or has served in the military and nearly one in four $(22.5 \%)$ has a father who serves or has served in the military. In individual cases, a distant relative $(8.0 \%)$ or the mother $(2.0 \%)$ serves or has served in the military. The characteristics of the respondents according to military traditions in the family are shown in Fig. 2. 


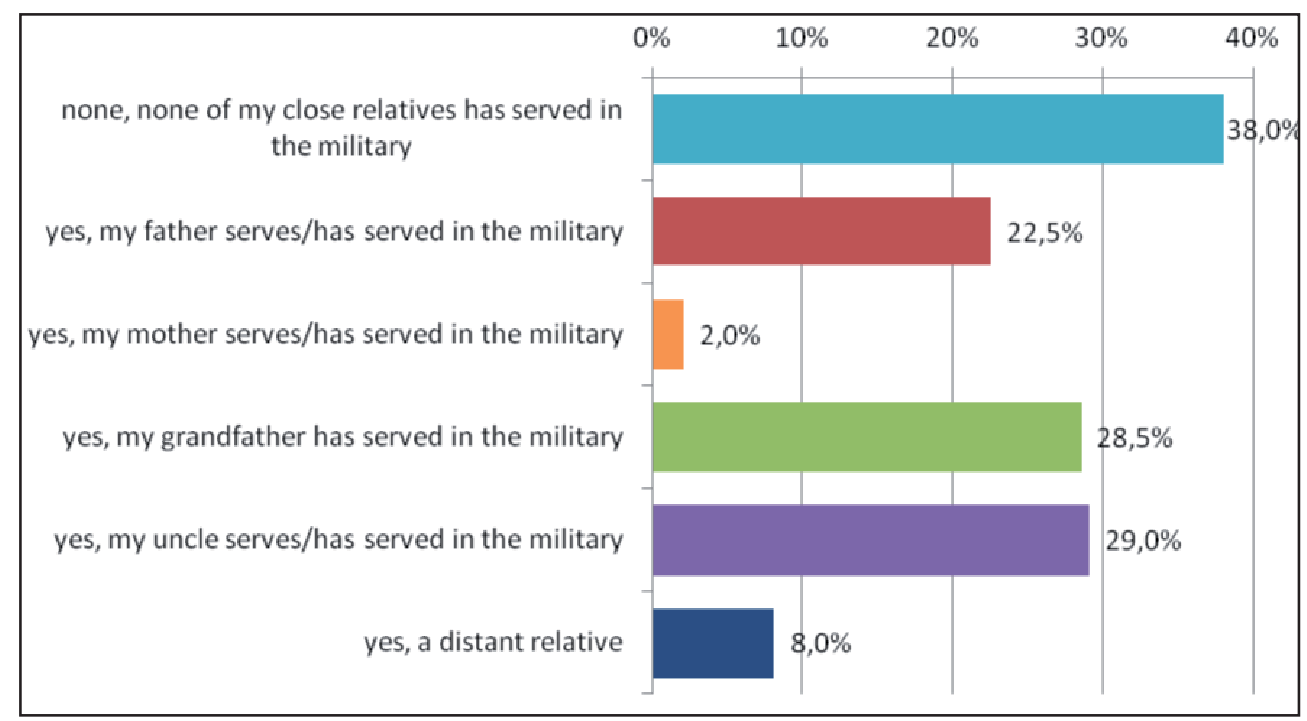

(The results do not add up to $100 \%$ due to the fact that many answers could be selected by the respondents.)

Fig. 2. Structure of the respondents according to military traditions in their families

\section{Social attitudes conducive to the strengthening of national security in the opinion of the participating students of military classes}

The study made it possible to determine the social attitudes that, in the opinion of students of military classes, were conducive to the strengthening of national security (Fig. 3). The attitudes that the students of military classes indicated as being conducive to the strengthening of national security were: respect for national security, tradition, and national symbols (93\%), patriotism (93\%), national awareness (92\%), respect for laws and customs (91\%), social activity (91\%), being raised in a family, respect for the family (90\%), cooperation skills (90\%), trust and honesty (89\%), feelings of social bonds, belonging, and community (84\%), building of a civil society ( $82 \%$ ). It must be emphasised that $3 / 4$ of the study group had no doubt that respect for national heritage, traditions, and national symbols, patriotism, and national awareness constituted the foundations of national security. 


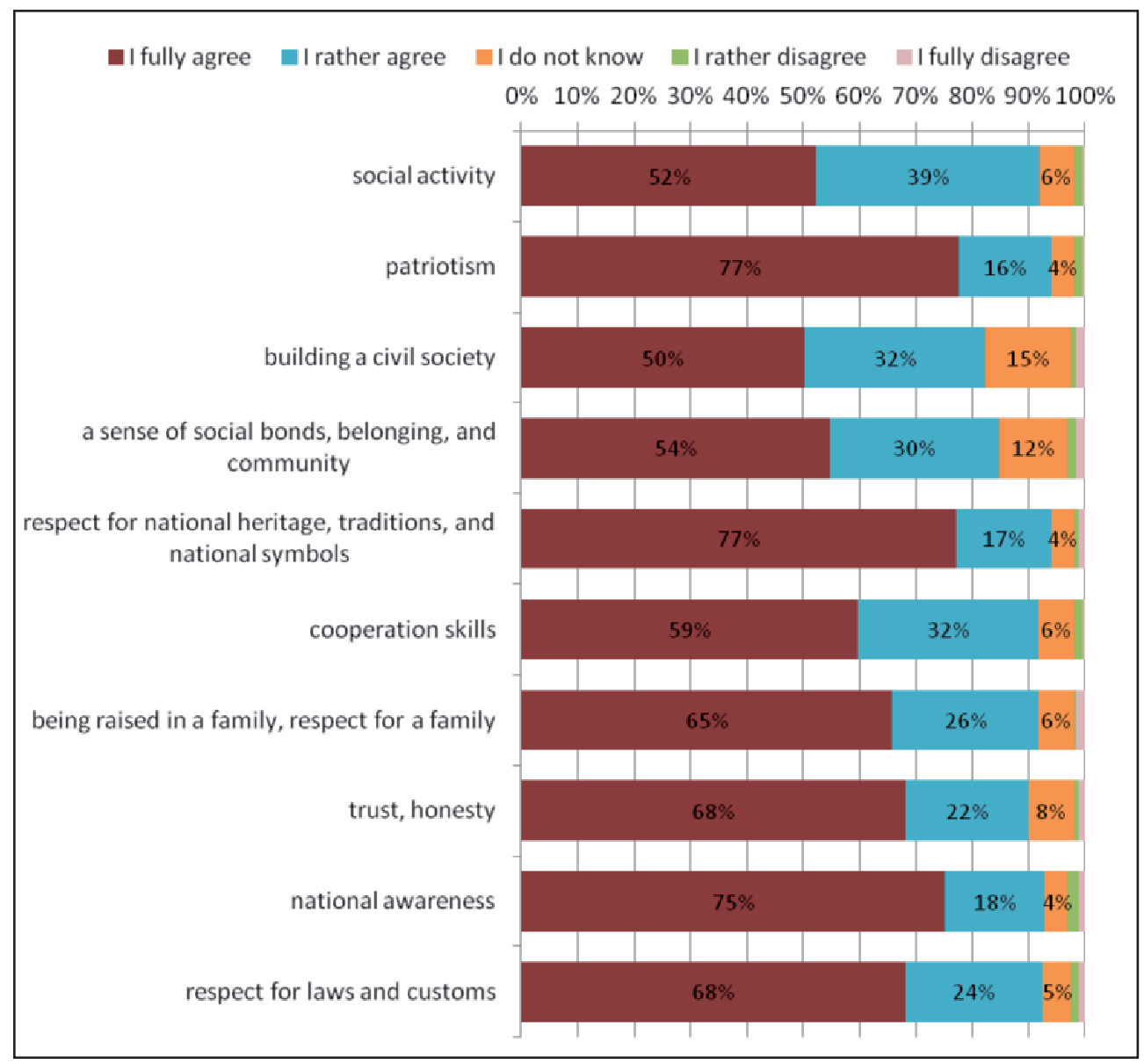

Fig. 3. Social attitudes conducive to the strengthening of national security in the opinion of students of military classes

The attitudes that men found to be conducive to the strengthening of national security were: patriotism (93\%), respect for national heritage, traditions, and national symbols (92\%), national awareness (92\%), social activity (91\%), and respect for laws and customs (90\%). The participating students found the building of civil society to be a little less important (80\%). None of the men participating in the study questioned such attitudes as being raised in a family and respect for the family. The social attitudes conducive to the strengthening of national security in the opinion of the participating men are shown in Fig. 4. 


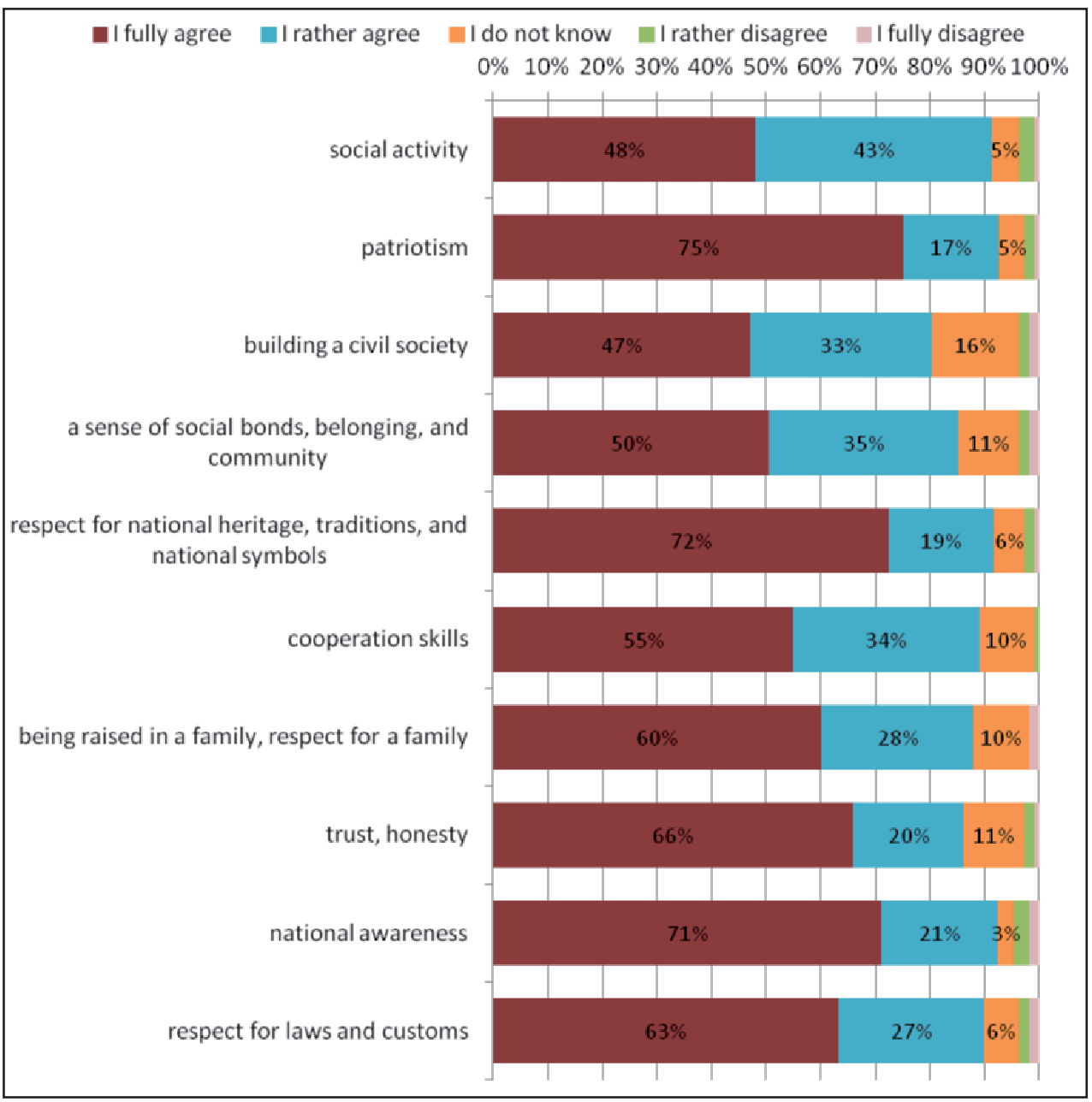

Fig. 4. The social attitudes conducive to the strengthening of national security in the opinion of the participating men

On the other hand, the attitudes that women found to be conducive to the strengthening of national security were respect for national heritage, traditions, and national symbols (95\%), being raised in a family, respect for a family (93\%), and respect for laws and customs (93\%). The female students found the sense of social bonds, belonging, and community to be less important (81\%). None of the women participating in the study questioned the importance of such attitudes as social activity, the building of a civil society, respect for national heritage, traditions, and national symbols, and trust and honesty. The social attitudes conducive to the strengthening of national security in the opinion of the participating women are shown in Fig. 5. 


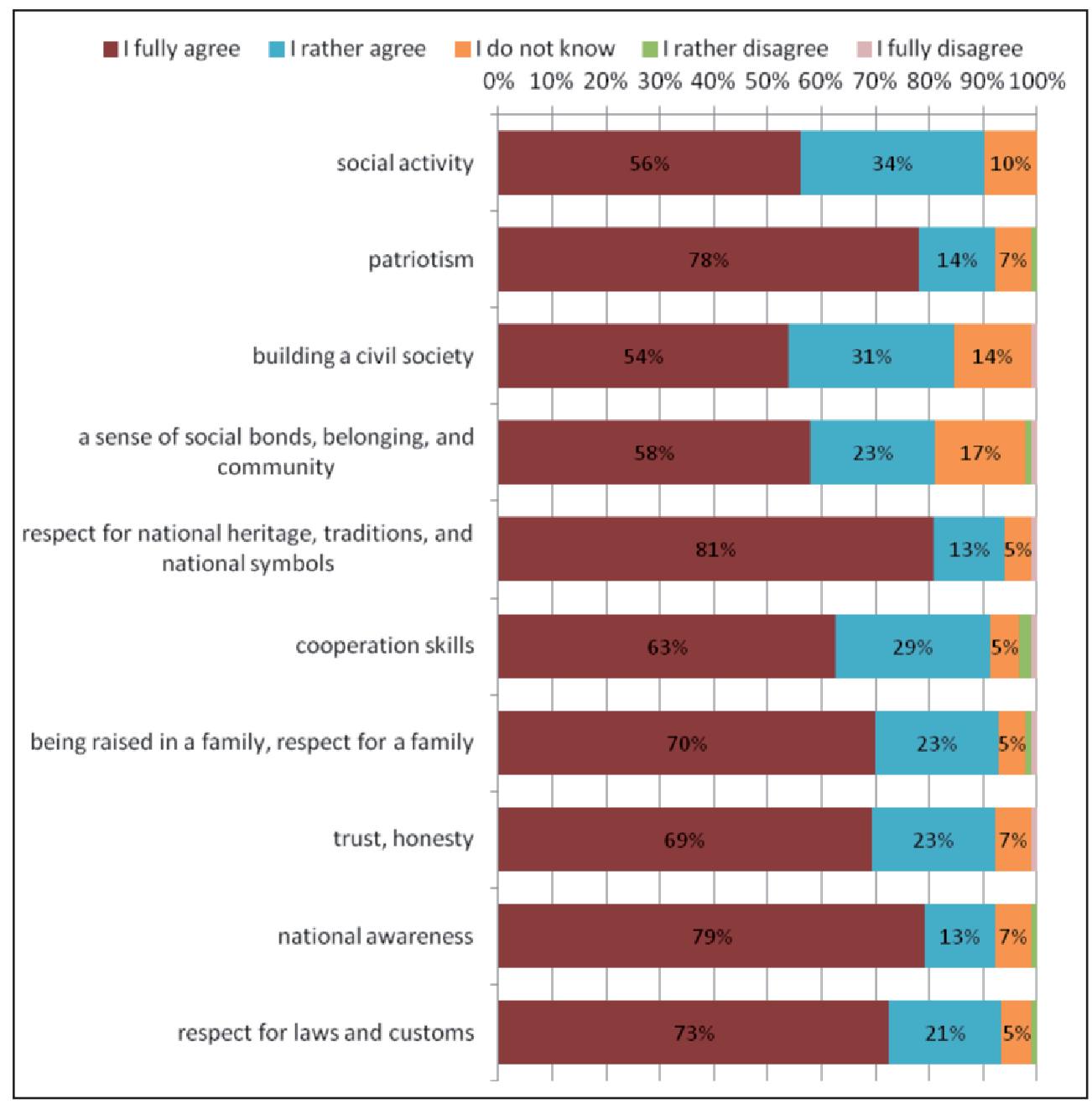

Fig. 5. The social attitudes conducive to the strengthening of national security in the opinion of the participating women

In conclusion, students of military classes found the following attitudes to be conducive to the strengthening of national security: respect for national heritage, traditions, and national symbols, patriotism, national awareness, respect for law and customs, social activity, being raised in a family and respect for the family, and cooperation skills. The men found a sense of patriotism, national awareness, and social activity to be important, while being raised in a family and respect for the family were important to women. The key social attitudes conducive to the strengthening of national security in the opinion of students of military classes are shown in Fig. 6. 


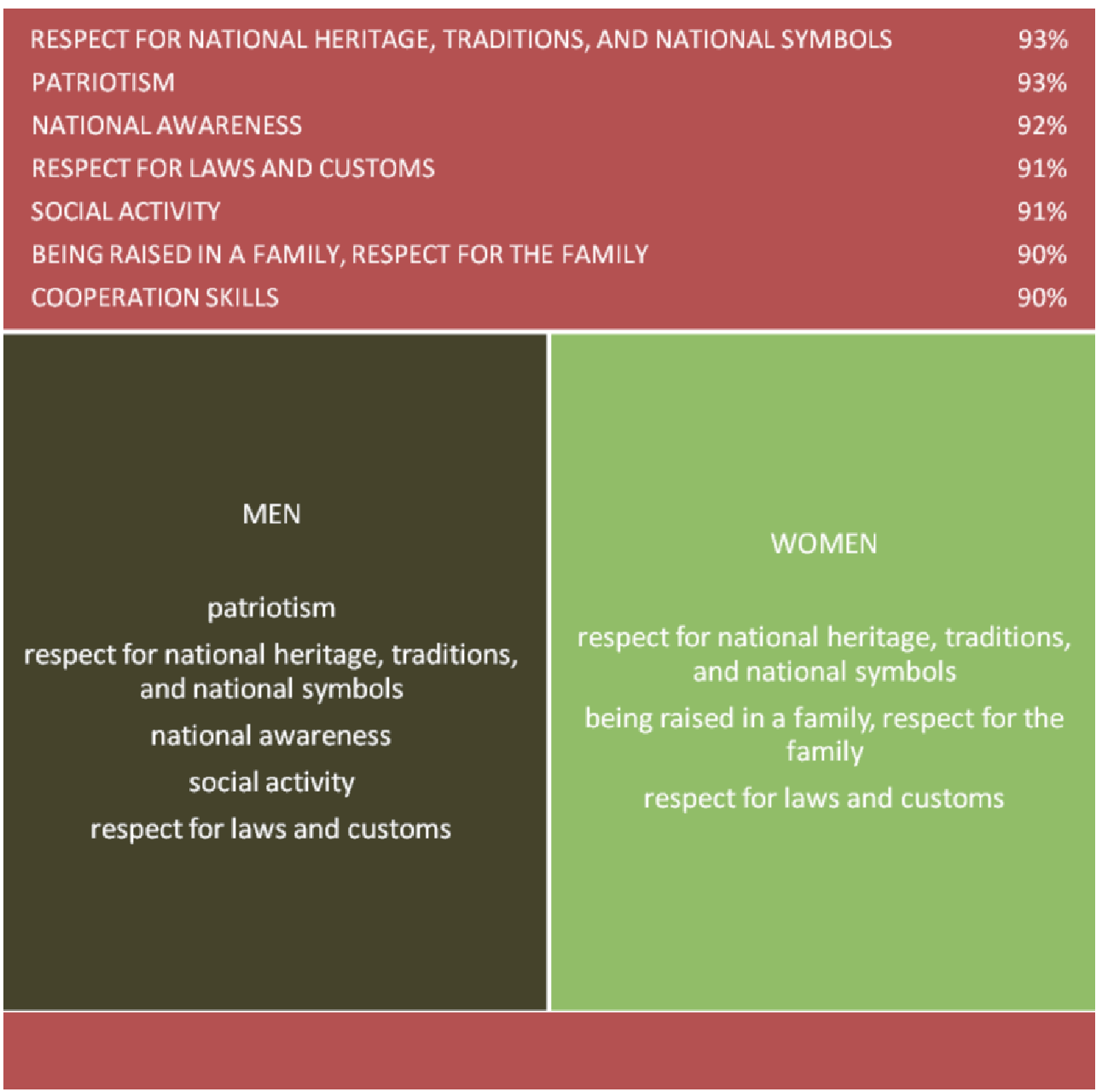

Fig. 6. The key social attitudes that are conducive to the strengthening of national security in the opinion of students of military classes

Of note is the fact that, taking into account the Pearson's coefficient, no significant correlations were found between the social attitudes and the independent variable of gender (cf. Table 1). 


\begin{tabular}{|l|l|l|l|}
\hline \multirow{2}{*}{$\begin{array}{l}\text { Social attitudes conducive to the } \\
\text { strengthening of national security }\end{array}$} & Variables & \multicolumn{2}{|l|}{} \\
\cline { 2 - 4 } Social activity & Gender & Age & Agglomeration \\
\cline { 2 - 4 } & 0,0828 & 0,0937 & 0,0416 \\
\cline { 2 - 4 } Patriotism & $\mathrm{p}=0.244$ & $\mathrm{p}=0.187$ & $\mathrm{p}=0.559$ \\
\cline { 2 - 4 } & 0,0359 & 0,0404 & 0,0995 \\
\hline \multirow{2}{*}{ Building a civil society } & $\mathrm{p}=0.614$ & $\mathrm{p}=0.570$ & $\mathrm{p}=0.161$ \\
\cline { 2 - 4 } & $\mathrm{p}=0.220$ & 0,0835 & 0,0234 \\
\hline Sense of social bonds, belonging, & 0,0342 & $\mathrm{p}=0.240$ & $\mathrm{p}=0.742$ \\
\cline { 2 - 4 } community & $\mathrm{p}=0.631$ & $\mathrm{p}=0.1230$ & 0,1584 \\
\hline Respect for national heritage, traditions, \\
and national symbols & 0,0918 & 0,0305 & $\mathrm{p}=0.025$ \\
\cline { 2 - 4 } Cooperation skills & $\mathrm{p}=0.196$ & $\mathrm{p}=0.668$ & 0,0810 \\
\hline \multirow{2}{*}{$\begin{array}{l}\text { Being raised in a family, respect for the } \\
\text { family }\end{array}$} & 0,0422 & 0,0834 & $\mathrm{p}=0.254$ \\
\cline { 2 - 4 } Trust, honesty & $\mathrm{p}=0.553$ & $\mathrm{p}=0.240$ & $\mathrm{p}=0.665$ \\
\cline { 2 - 4 } & $\mathrm{p}=0.1095$ & 0,0747 & 0,1246 \\
\hline \multirow{2}{*}{ National awareness } & 0,0684 & $\mathrm{p}=0.293$ & $\mathrm{p}=0.079$ \\
\cline { 2 - 4 } & $\mathrm{p}=0.336$ & 0,0622 & 0,0813 \\
\hline \multirow{2}{*}{ Respect for laws and customs } & 0,0944 & $\mathrm{p}=0.382$ & $\mathrm{p}=0.252$ \\
\cline { 2 - 4 } & $\mathrm{p}=0.184$ & $\mathrm{p}=0.941$ & $\mathrm{p}=0.080$ \\
\hline & 0,1123 & 0,0320 & 0,1210 \\
\cline { 2 - 4 } & $\mathrm{p}=0.113$ & $\mathrm{p}=0.653$ & $\mathrm{p}=0.088$ \\
\hline
\end{tabular}

Table 1. Analysis of the correlation between social attitudes and the independent variable (gender) taking into account the Pearson's coefficient

\section{Factors shaping national identity in the opinion of the participating students of military classes}

The objective of the study was to identify the factors that, in the opinion of the respondents, shape the national identity (cf. Fig. 7). An analysis of the results of the study proves that, in the opinion of students of military classes, national identity is shaped by language (96\%), knowledge of history and national heritage (94\%), patriotic education (92\%), community of symbols and respect for them (91\%), cultivation of national traditions (90\%), education (88\%), common culture and values (87\%), common good and group interests (78\%), family, religiousness, and Christian religion (74\%). 


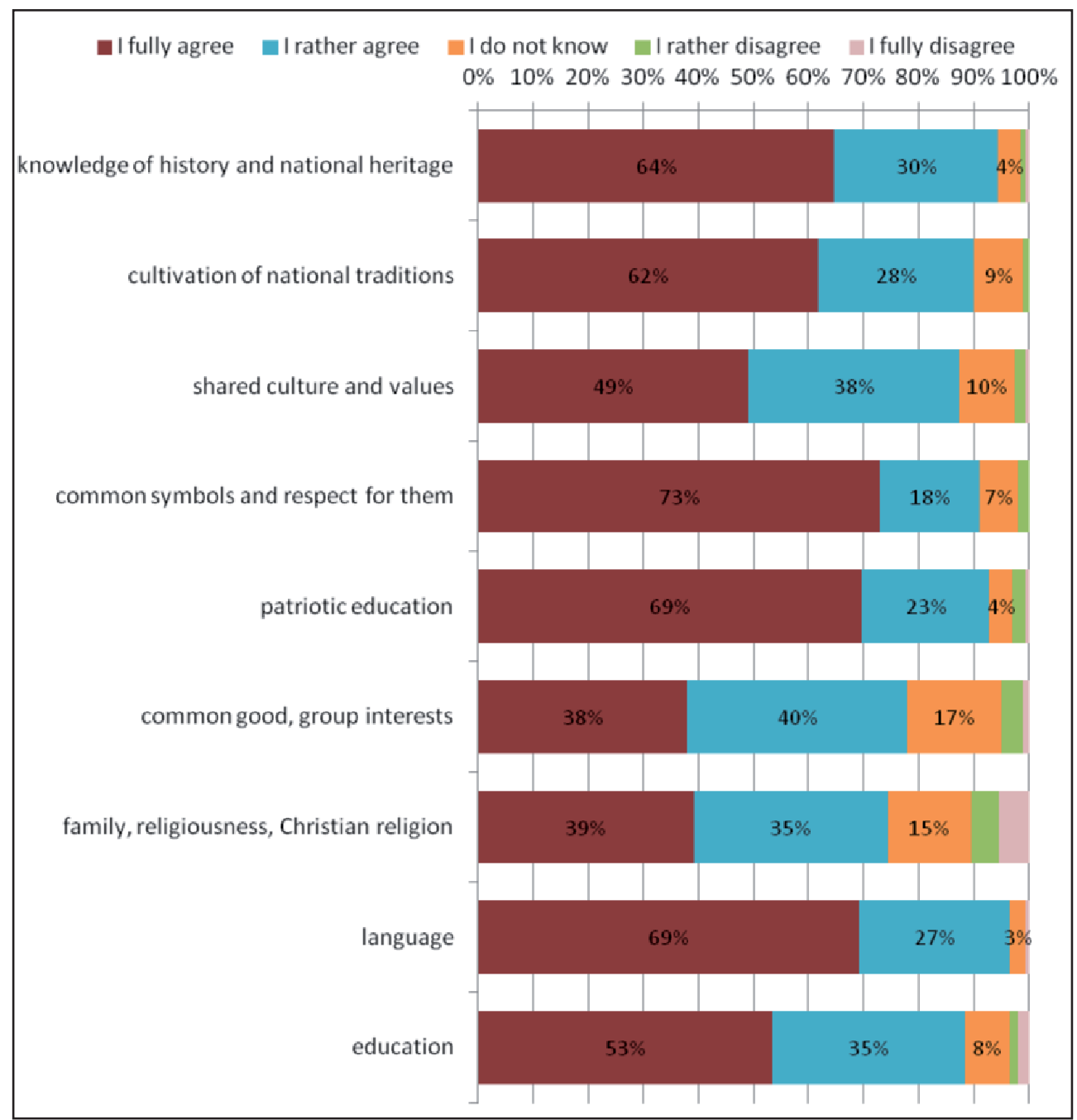

Fig. 7. Factors shaping national identity in the opinion of students of military classes

In the opinion of the men participating in the study, national identity was shaped most of all by language (96\%), knowledge of history and national heritage (93\%), patriotic education (92\%), and common symbols and respect for them (90\%). On the other hand, they found family, religiousness, and Christian religion to be the least important (68\%). The factors shaping national identity in the opinion of the participating men are shown in Fig. 8. 


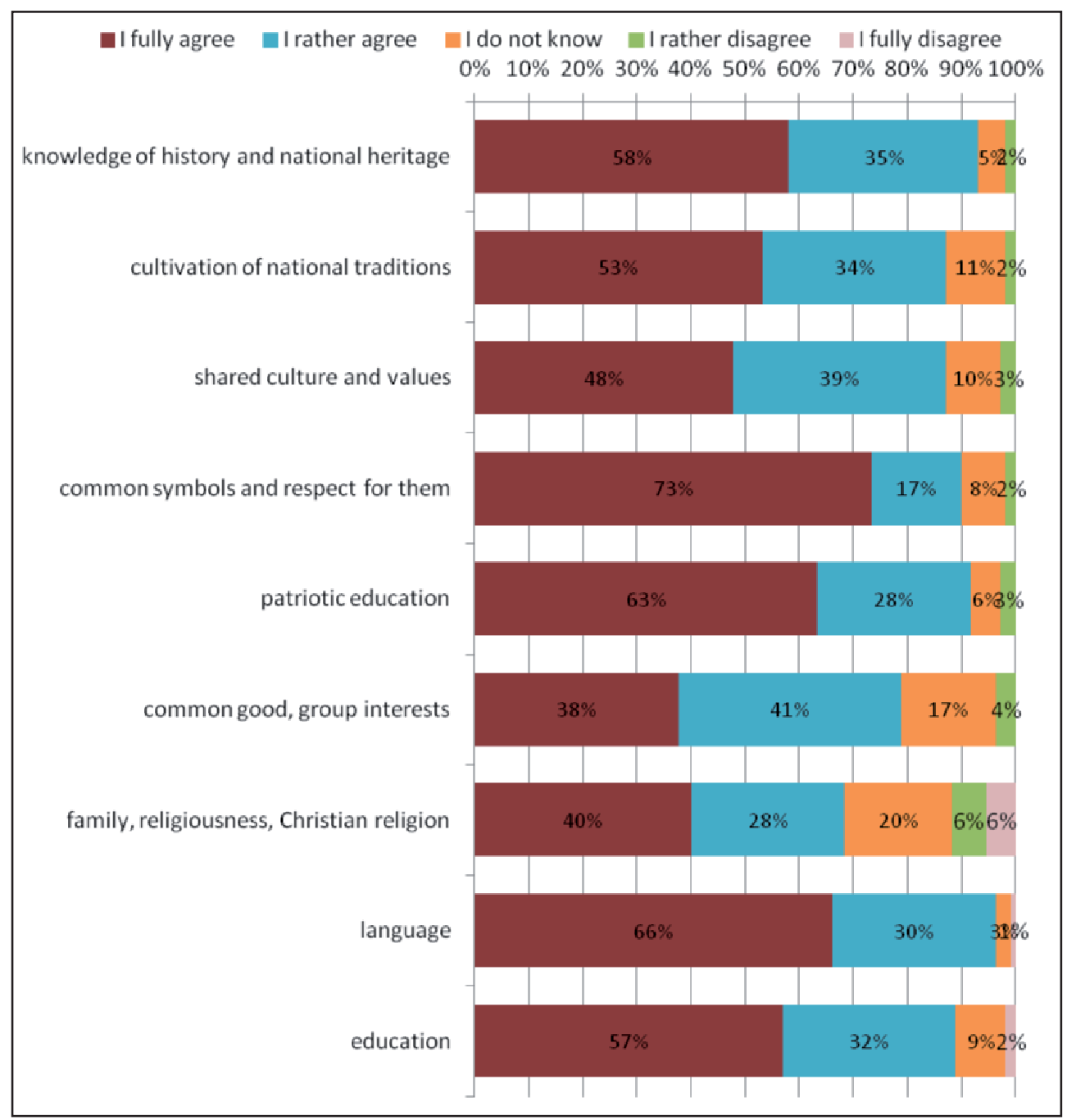

Fig. 8. Factors shaping national identity in the opinion of the participating men

On the other hand, the participating women believed that national identity is shaped, most of all, by knowledge of history and national heritage (95\%), language (94\%), cultivation of national traditions (92), common symbols and respect for them (92\%), and patriotic education (92\%). Women found common good and group interests to be the least important (77\%). The factors shaping national identity in the opinion of the participating women are shown in Fig. 9. 


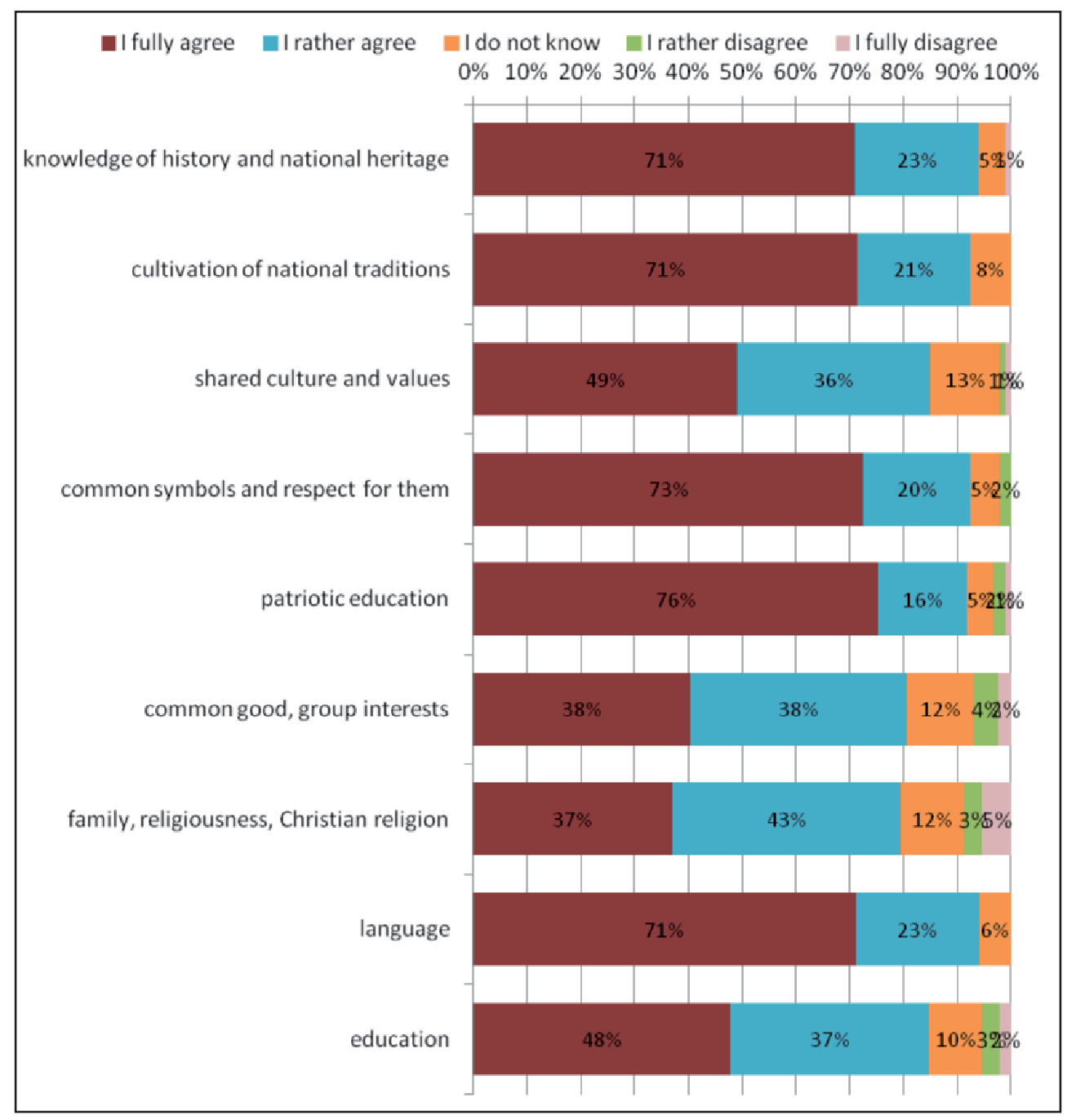

Fig. 9. Factors shaping national identity in the opinion of the participating women

In conclusion, in the opinion of students of military classes, national identity is shaped most of all by such factors as language, knowledge of history and heritage, patriotic education, common symbols and respect for them, and cultivation of national traditions (cf. Fig. 10). 


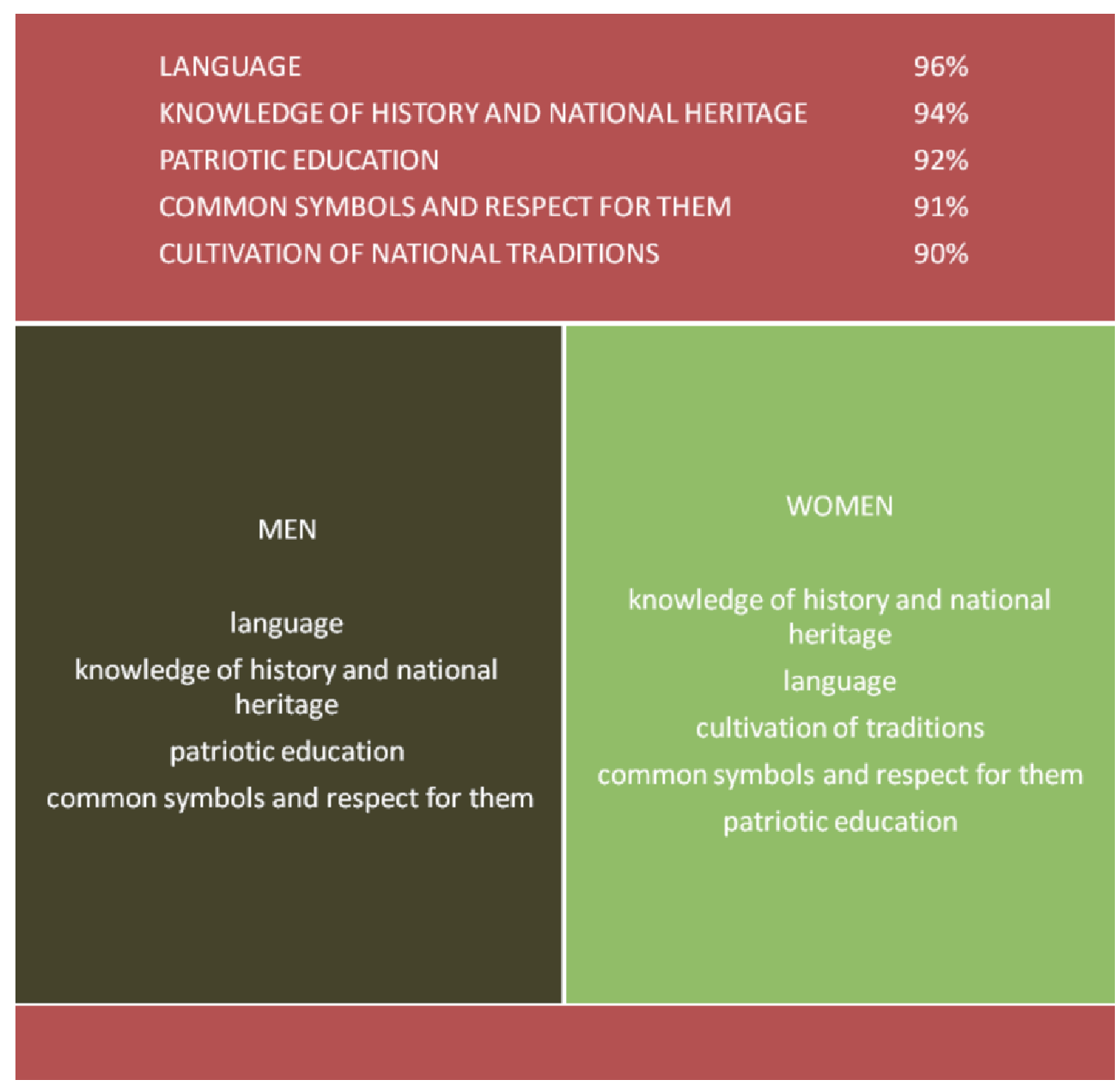

Fig. 10. Main factors shaping national identity in the opinion of students of military classes

An analysis of the results made it possible to conclude that there is a correlation between the factors shaping national identity and the independent variable (gender), taking into account the Pearson's coefficient (cf. Table 2). Thus, it should be pointed out that women much more often than men indicated that the factor that shapes national identity was the cultivation of national traditions. 


\begin{tabular}{|l|l|l|l|}
\hline \multirow{2}{*}{ Factors shaping national identity } & Variables & \multicolumn{2}{|l|}{} \\
\cline { 2 - 4 } & Gender & Age & Agglomeration \\
\hline \multirow{2}{*}{$\begin{array}{l}\text { Knowledge of history and national } \\
\text { Cultivation of national traditions }\end{array}$} & 0.1101 & 0.0487 & 0.0832 \\
\cline { 2 - 4 } & $\mathrm{p}=0.121$ & $\mathrm{p}=0.493$ & $\mathrm{p}=0.242$ \\
\hline \multirow{2}{*}{ Common culture and values } & 0,1775 & 0.0950 & 0.0965 \\
\cline { 2 - 4 } & $\mathrm{p}=0.012$ & $\mathrm{p}=0.181$ & $\mathrm{p}=0.174$ \\
\hline \multirow{2}{*}{ Common symbols and respect for them } & 0.0015 & 0.0482 & 0.0486 \\
\cline { 2 - 4 } & $\mathrm{p}=0.983$ & $\mathrm{p}=0.498$ & $\mathrm{p}=0.494$ \\
\cline { 2 - 4 } & 0.0083 & 0.0202 & 0.1291 \\
\hline \multirow{2}{*}{ Patriotic education } & $\mathrm{p}=0.907$ & $\mathrm{p}=0.777$ & $\mathrm{p}=0.069$ \\
\cline { 2 - 4 } & $\mathrm{p}=0.0765$ & 0.0500 & 0,1617 \\
\hline \multirow{2}{*}{ Fommon good, group interests } & 0.0350 & $\mathrm{p}=0.482$ & $\mathrm{p}=0.022$ \\
\cline { 2 - 4 } & $\mathrm{p}=0.623$ & 0.0871 & 0.1163 \\
\hline \multirow{2}{*}{ Language } & 0.0517 & $\mathrm{p}=0.220$ & $\mathrm{p}=0.101$ \\
\cline { 2 - 4 } & $\mathrm{p}=0.467$ & $\mathrm{p}=0.2009$ & 0.0597 \\
\hline \multirow{2}{*}{ Education } & 0.0439 & 0.0154 & $\mathrm{p}=0.401$ \\
\cline { 2 - 4 } & $\mathrm{p}=0.537$ & $\mathrm{p}=0.829$ & $\mathrm{p}=0.245$ \\
\hline & 0.0918 & 0.0160 & 0.0488 \\
\cline { 2 - 4 } & $\mathrm{p}=0.196$ & $\mathrm{p}=0.822$ & $\mathrm{p}=0.492$ \\
\hline
\end{tabular}

Table 2. An analysis of the correlation between the factors shaping national identity and the independent variable (gender), taking into account the Pearson's coefficient

\section{Threats to national security in the opinion of the participating students of military classes}

The participating students identified the following key threats to national security: international criminal activity and terrorism $83 \%$, international armed conflicts (83\%), migration of people (79\%), fights between states for dominance and geopolitical changes (77\%), instability of alliances among states (76\%), threats in cyberspace (61\%), spread of radical ideologies and nationalism (57\%), hybrid conflicts (57\%), atheisation of Europe and a crisis of values (55\%), insufficient level of diversification of sources of energy raw materials (53\%). The respondents most often did not agree with the statement that a threat is posed by cyberspace (18\%), atheisation of Europe and a crisis of values (18\%), spread of radical ideologies and 
nationalism (15\%), and insufficient level of diversification of sources of energy raw materials (11\%). The contemporary threats to national security in the opinion of the participating students of military classes are shown in Fig. $11 .^{2}$

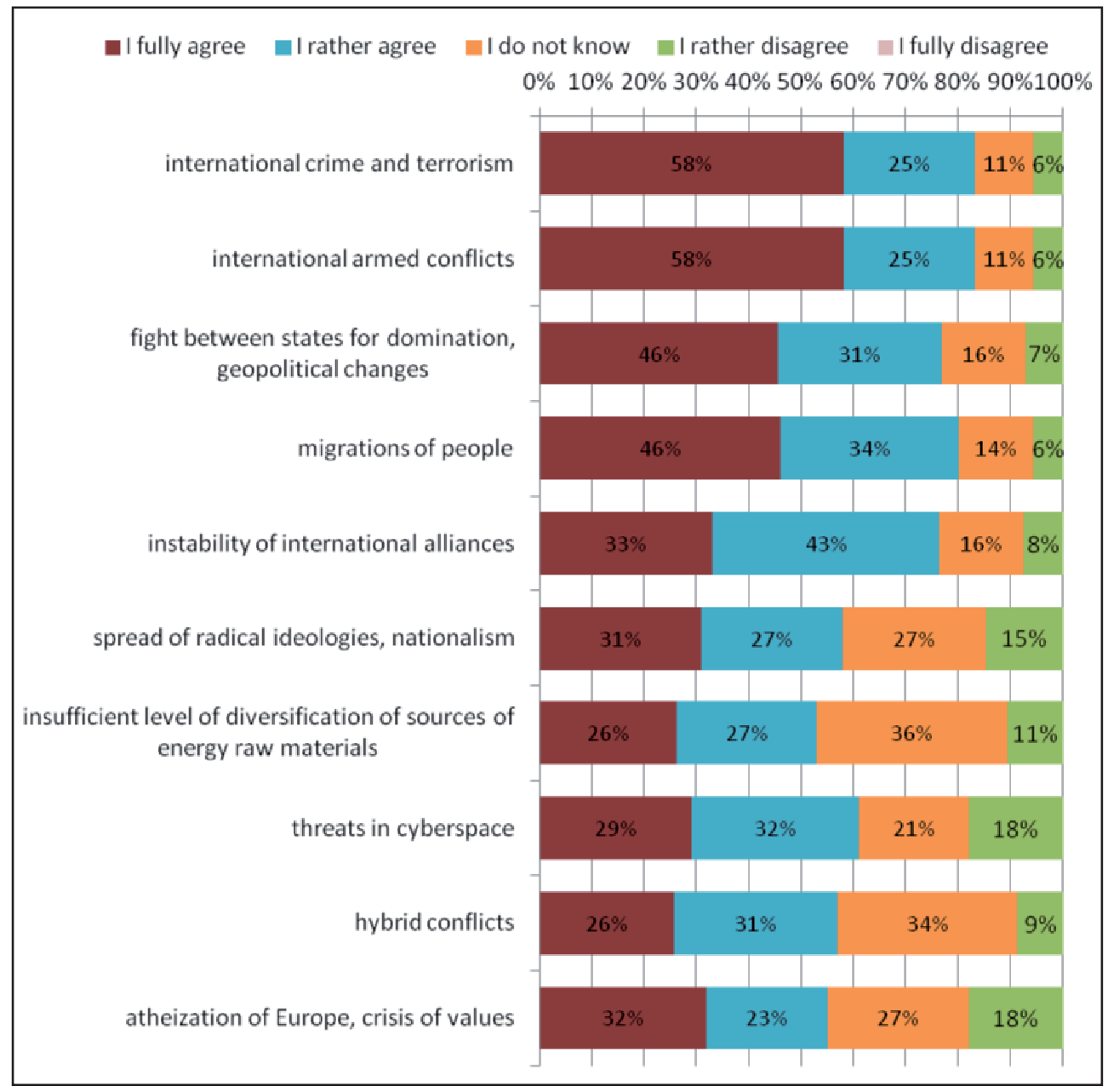

Fig. 11. Contemporary threats to national security in the opinion of students of military classes

2 The list of threats to the national security has been created based on an analysis of the results of studies in the form of expert interviews performed as a part of the project titled Cultural identity of Poles and the security of Poles. The project has been performed for the National Center for Culture in Warsaw by the Chair of Education and Non-Government Forms of Security of the Faculty of National Security of the War Studies University in 2016. 
The participating men identified the following key threats to national security: international crime and terrorism (79\%), international armed conflicts (79\%), instability of alliances between states (77\%), and migrations of people (76\%). The male respondents most often did not agree with the statement that the atheisation of Europe and the crisis of values (49\%) constituted threats to national security. The opinions of the participating men about the contemporary threats to national security are shown in Fig. 12.

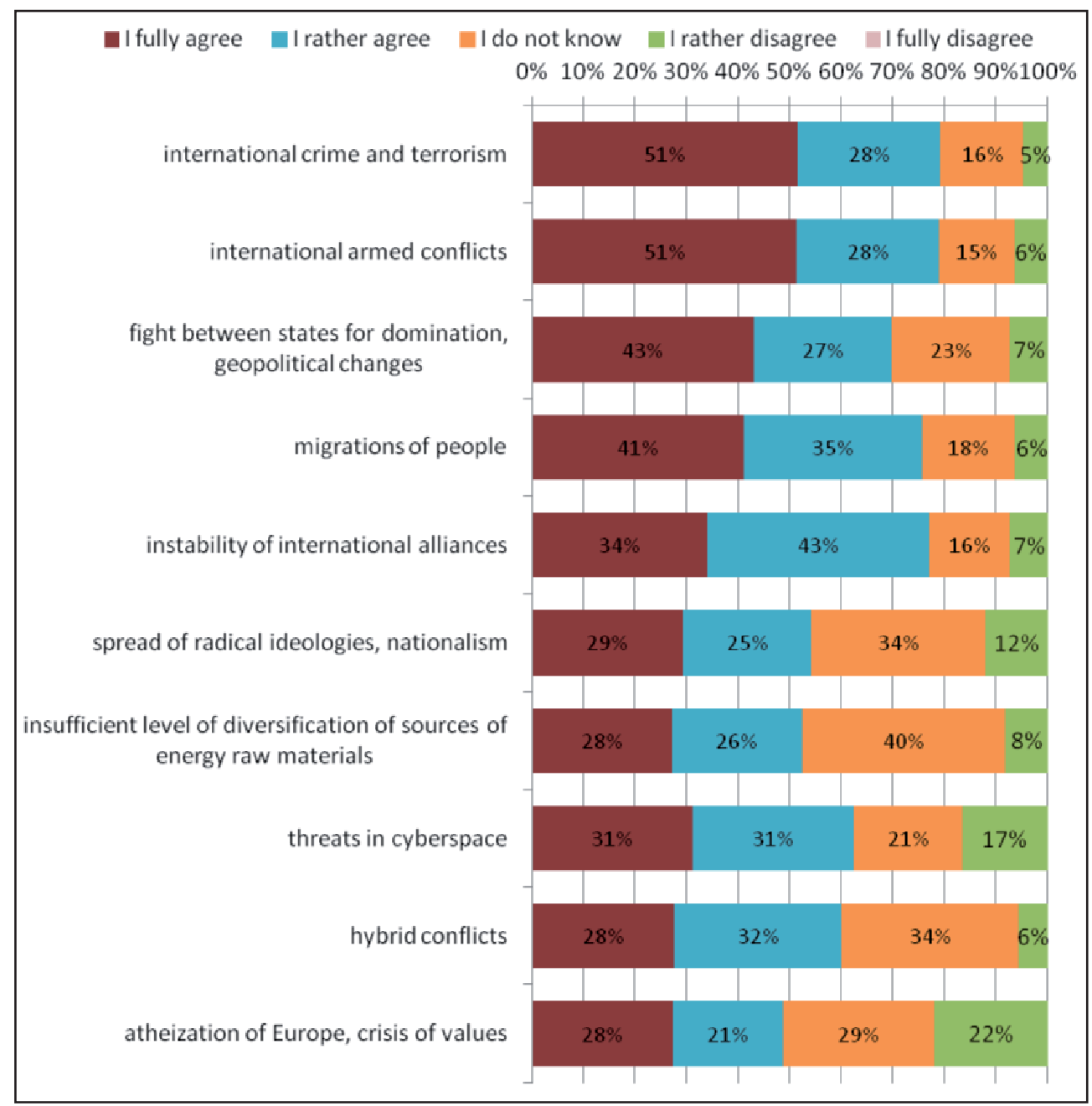

Fig. 12. Contemporary threats to national security in the opinion of participating men 
The participating women most often identified the following threats to national security: international armed conflicts "87\%), international crime and terrorism (86\%), fights between states for domination and geopolitical changes (85\%), and migration of people (82\%). The female respondents most often did not agree with the statement that hybrid conflicts (53) and insufficient level of diversification of sources of energy raw materials (52\%) constitute a threat to national security. The opinions of the participating women about the contemporary threats to national security are shown in Fig. 13.

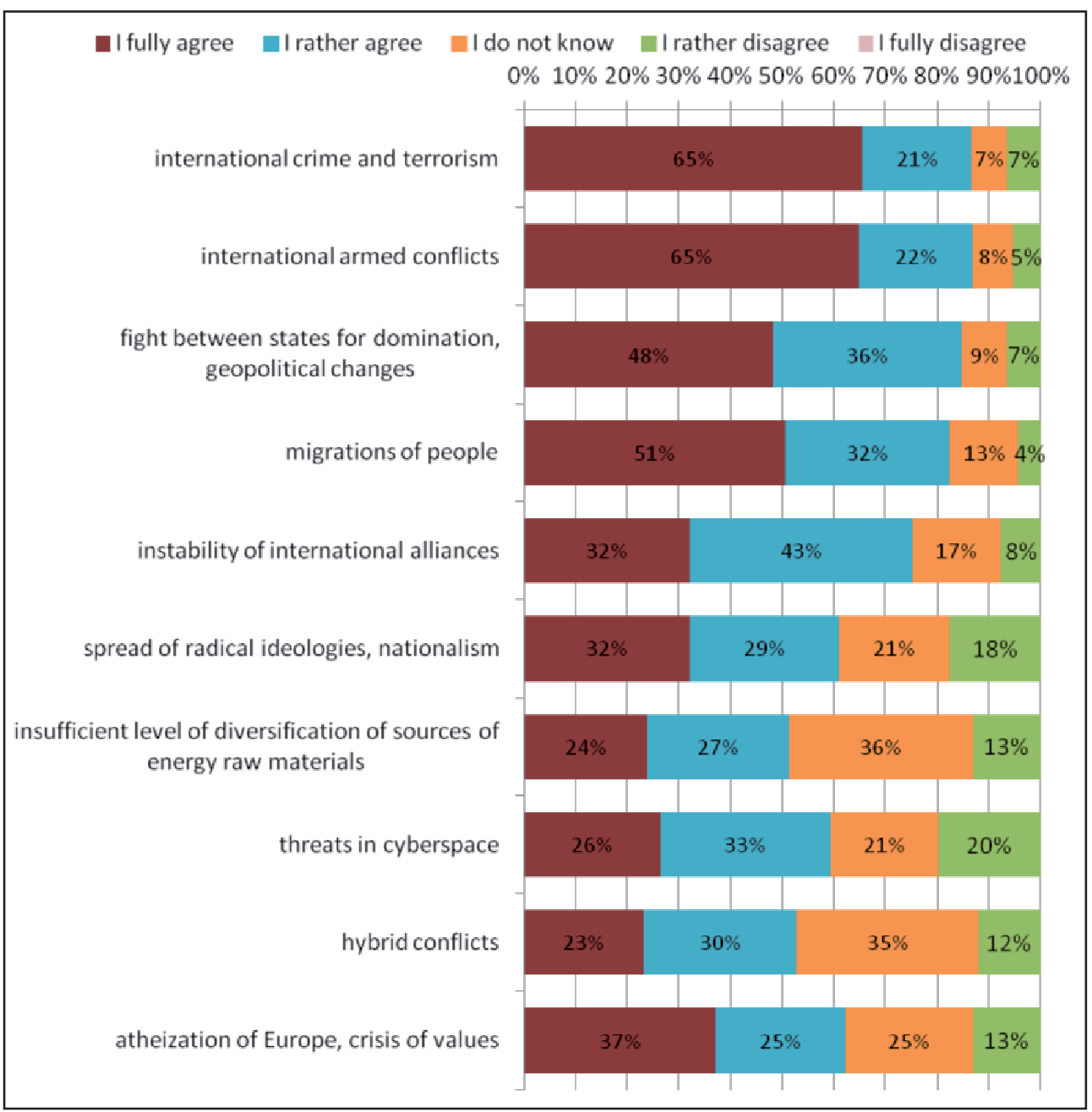

Fig. 13. Contemporary threats to national security in the opinion of participating women 
In conclusion, in the opinion of students of military classes, the contemporary threats to national security are: international crime and terrorism, international armed conflicts, migration of people, fights between states for domination and geopolitical changes, and the instability of alliances between states (cf. Fig. 14).

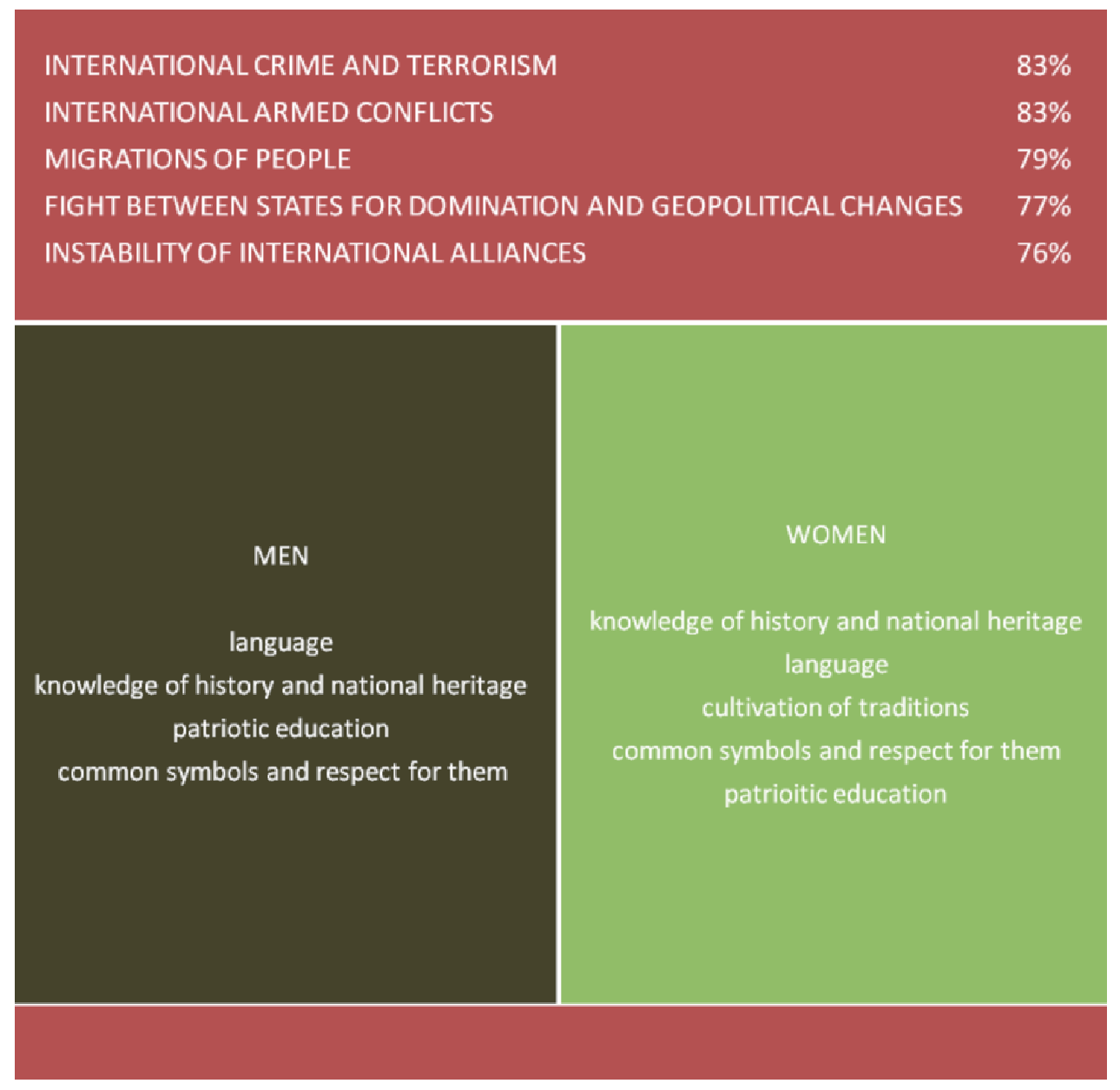

Fig. 14. Contemporary threats to national security in the opinion of students of military classes

It was statically determined that women significantly more often than men identified the atheisation of Europe and a crisis of values as a threat to national security. In the case of the other analysed factors, the distribution of the responses on the study groups was comparable and no significant correlations were found among them (cf. Table 3). 


\begin{tabular}{|c|c|c|c|}
\hline \multirow{2}{*}{$\begin{array}{l}\text { Contemporary threats to national } \\
\text { security }\end{array}$} & \multicolumn{3}{|l|}{ Variables } \\
\hline & Gender & Age & Agglomeration \\
\hline \multirow{2}{*}{ International crime, terrorism } & 0.1081 & 0.0595 & 0.0434 \\
\hline & $\mathrm{p}=0.128$ & $\mathrm{p}=0.402$ & $\mathrm{p}=0.542$ \\
\hline \multirow{2}{*}{ International armed conflict } & 0.1231 & 0.0109 & 0.0255 \\
\hline & $\mathrm{p}=0.083$ & $\mathrm{p}=0.878$ & $\mathrm{p}=0.720$ \\
\hline \multirow{2}{*}{$\begin{array}{l}\text { Fights between states for domination, } \\
\text { geopolitical changes }\end{array}$} & 0.1109 & 0.0044 & 0.0885 \\
\hline & $\mathrm{p}=0.118$ & $\mathrm{p}=0.950$ & $\mathrm{p}=0.213$ \\
\hline \multirow{2}{*}{ Migration of people } & 0.0982 & 0.0997 & 0.0934 \\
\hline & $\mathrm{p}=0.167$ & $\mathrm{p}=0.160$ & $\mathrm{p}=0.188$ \\
\hline \multirow{2}{*}{ Instability of alliances between states } & 0.0266 & 0.0397 & 0.1073 \\
\hline & $\mathrm{p}=0.708$ & $p=0.577$ & $\mathrm{p}=0.131$ \\
\hline \multirow{2}{*}{$\begin{array}{l}\text { Spreading of radical ideologies, } \\
\text { nationalism }\end{array}$} & 0.0151 & 0.0572 & 0.0839 \\
\hline & $\mathrm{p}=0.832$ & $\mathrm{p}=0.421$ & $\mathrm{p}=0.237$ \\
\hline \multirow{2}{*}{$\begin{array}{l}\text { Insufficient level of diversification of } \\
\text { sources of energy raw materials }\end{array}$} & 0.0503 & 0.0323 & 0,1380 \\
\hline & $\mathrm{p}=0.479$ & $\mathrm{p}=0.649$ & $\mathrm{p}=0.051$ \\
\hline \multirow{2}{*}{ Threats in the cyberspace } & 0.0519 & 0.0019 & 0.0044 \\
\hline & $\mathrm{p}=0.466$ & $\mathrm{p}=0.979$ & $\mathrm{p}=0.951$ \\
\hline \multirow{2}{*}{ Hybrid conflicts } & 0.0954 & 0.0054 & 0.0489 \\
\hline & $\mathrm{p}=0.179$ & $\mathrm{p}=0.940$ & $\mathrm{p}=0.492$ \\
\hline \multirow{2}{*}{ Atheisation of Europe, a crisis of values } & 0,1477 & 0.0848 & 0.0359 \\
\hline & $\mathrm{p}=0.037$ & $\mathrm{p}=0.232$ & $\mathrm{p}=0.614$ \\
\hline
\end{tabular}

Table 3. Analysis of correlation between threats to national security and the independent variable (gender), taking into account the Pearson's coefficient

\section{Sources of knowledge of students of military classes about contemporary threats to national security}

Based on the analyses conducted as part of the study, it can be identified that the knowledge of students of military classes about threats to national security was shaped most of all by the Internet (68\%), teachers/educators (51\%), books, press, radio, and television (49\%), the class they attended (29\%), and parents (29\%). One in four respondents identified the existing threats themselves (25\%) or used the opinions of his or her friends (24\%). In gaining knowledge in this area, the respondent most rarely used national traditions (20\%), school books (14\%), other family members (12\%), family traditions (9\%), religion (8\%), and computer games (5\%). The sources of knowledge of students of military classes about contemporary threats to national security are shown in Fig. 15. 


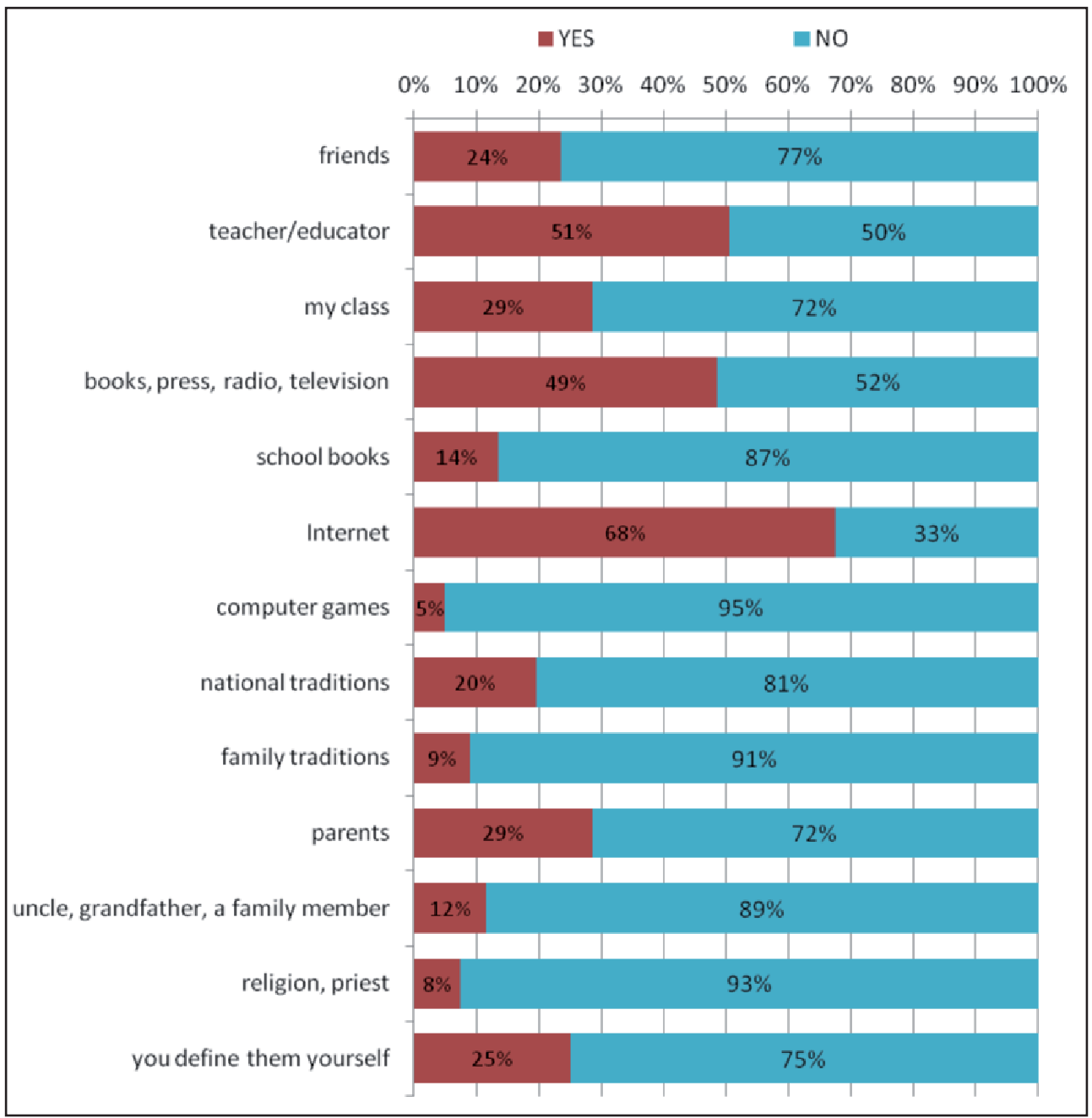

Fig. 15. Sources of knowledge of participating students about contemporary threats to national security

The participating men gained their knowledge about contemporary threats to national security most of all from the Internet (70\%), teachers/educators (52\%), and such media as books, press, radio, and television (45\%). One in three respondents (31\%) stated that he identified the existing threats himself (cf. Fig. 16). 


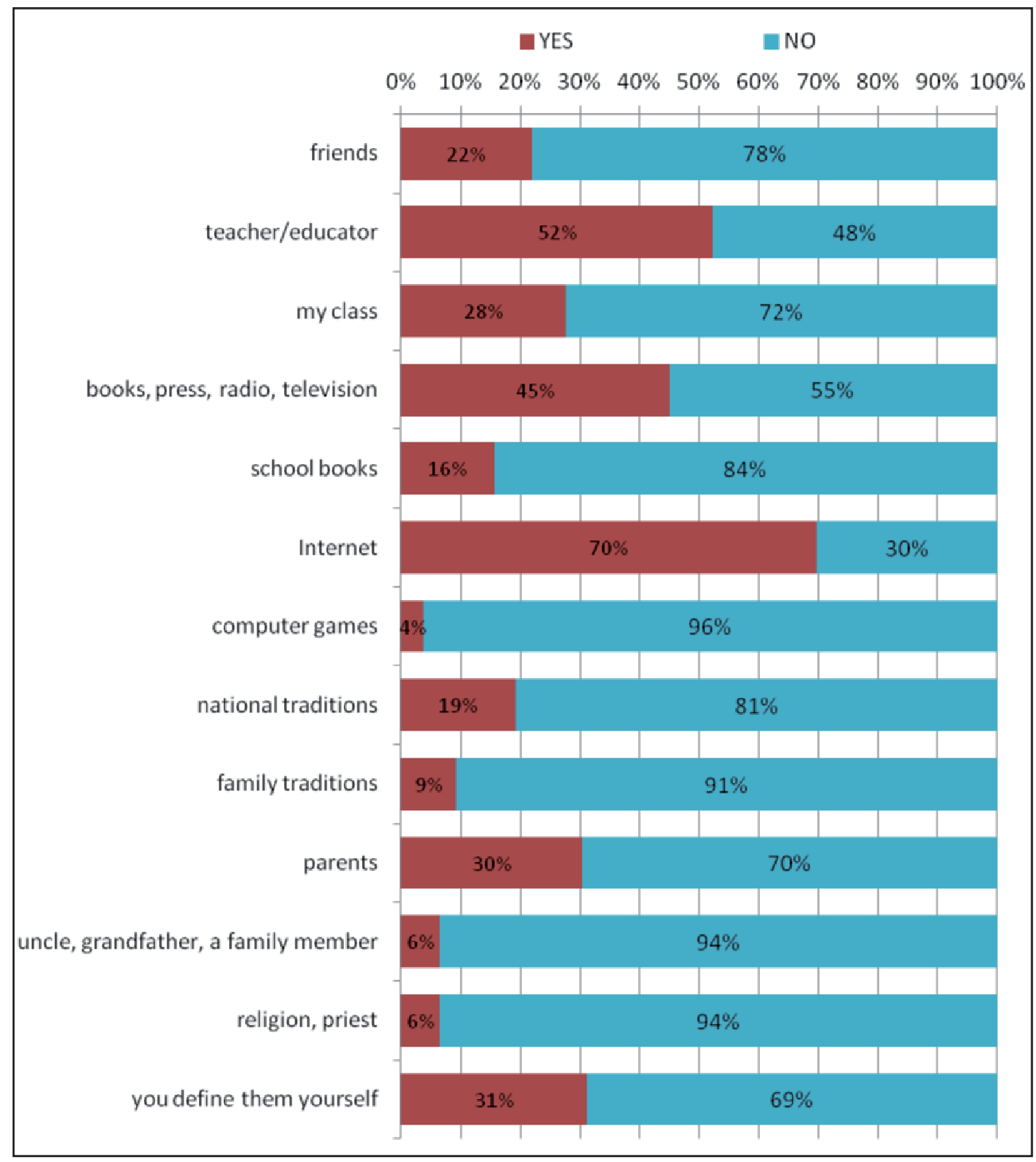

Fig. 16. Sources of knowledge of participating men about contemporary threats to national security

The participating women gained their knowledge about contemporary threats to national security most of all from the Internet (65\%), books, press, radio, and television (53\%), and teachers/educators (48\%). One out of five (18\%) female respondents stated that she identified the existing threats herself. The sources of knowledge of participating women about contemporary threats to national security are shown in Fig. 17. 


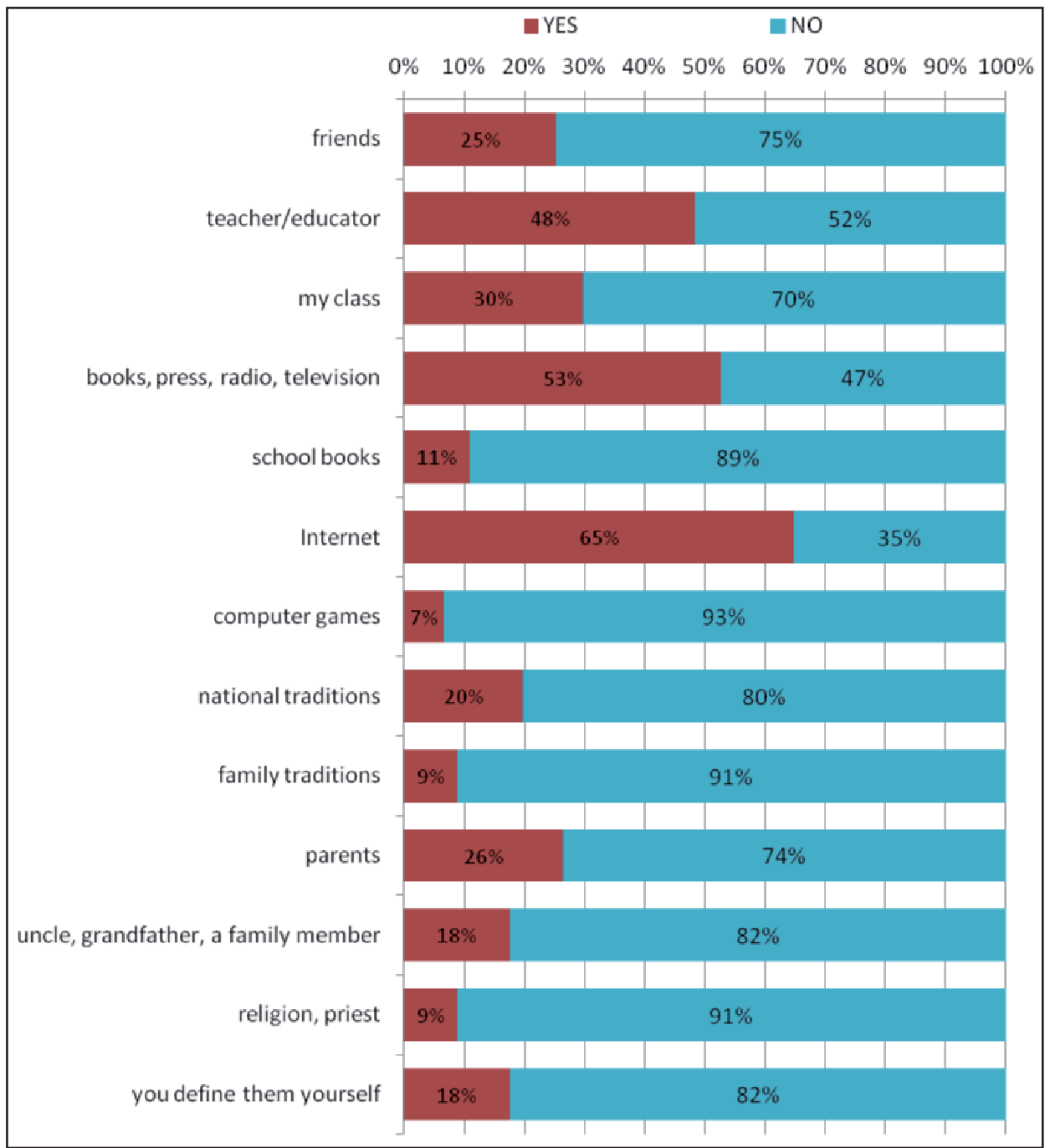

Fig. 17. Sources of knowledge of participating women about contemporary threats to national security

In conclusion, the students get their knowledge about contemporary threats to national security from the Internet, their teachers/educators, books, press, radio, and television, other members of their classes, and their parents. Regardless of their gender and age, the primary source of their knowledge is the Internet. Women and students of the third grade more often based their knowledge on information obtained on their own (books, press, radio, television), while men and students of the first and second grade based their knowledge on information provided by teachers and educators (cf. Fig. 18). 


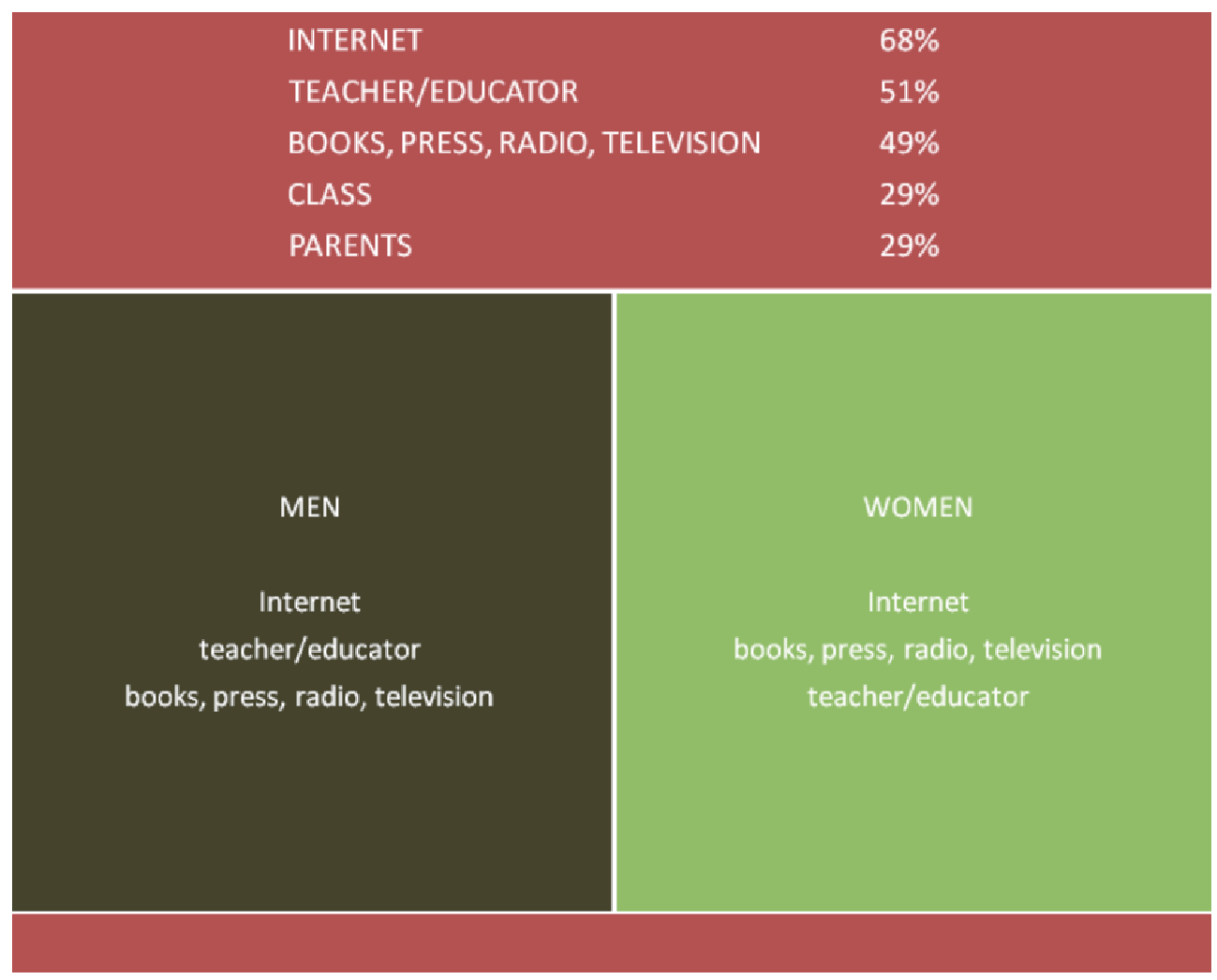

Fig. 18. Sources of knowledge of students of military classes about contemporary threats to national security

It was found statistically that men significantly more often than women determined the existing threats to national security on their own. In the case of the other analysed factors, the distribution of the responses on the study groups was comparable and no significant correlations were found among them (cf. Table 4).

\begin{tabular}{|c|c|c|c|}
\hline \multirow{2}{*}{$\begin{array}{l}\text { Sources of knowledge about } \\
\text { contemporary threats to national } \\
\text { security }\end{array}$} & \multicolumn{3}{|c|}{ Variables } \\
\hline & Gender & Age & Agglomeration \\
\hline \multirow{2}{*}{ Friends } & 0.0382 & 0.0862 & 0.1124 \\
\hline & $\mathrm{p}=0.591$ & $\mathrm{p}=0.225$ & $\mathrm{p}=0.113$ \\
\hline \multirow{2}{*}{ Teachers, educators } & 0.0393 & 0.1196 & 0.0755 \\
\hline & $\mathrm{p}=0.581$ & $\mathrm{p}=0.092$ & $\mathrm{p}=0.288$ \\
\hline \multirow{2}{*}{ The attended class } & 0.0237 & 0,1440 & 0.0602 \\
\hline & $\mathrm{p}=0.739$ & $\mathrm{p}=0.042$ & $\mathrm{p}=0.397$ \\
\hline \multirow{2}{*}{ Books, press, radio, television } & 0.0776 & 0.0507 & 0.0236 \\
\hline & $\mathrm{p}=0.274$ & $\mathrm{p}=0.475$ & $\mathrm{p}=0.740$ \\
\hline
\end{tabular}




\begin{tabular}{|l|l|l|l|}
\hline \multirow{2}{*}{$\begin{array}{l}\text { Sources of knowledge about } \\
\text { contemporary threats to national } \\
\text { security }\end{array}$} & Variables & \multicolumn{2}{|l|}{} \\
\cline { 2 - 4 } & Gender & Age & Agglomeration \\
\hline \multirow{2}{*}{ School books } & 0.0671 & 0.0035 & 0.1338 \\
\cline { 2 - 4 } & $\mathrm{p}=0.345$ & $\mathrm{p}=0.961$ & $\mathrm{p}=0.059$ \\
\hline \multirow{2}{*}{ Comp Internet } & 0.0520 & 0.0399 & 0.0364 \\
\cline { 2 - 4 } & $\mathrm{p}=0.465$ & $\mathrm{p}=0.574$ & $\mathrm{p}=0.609$ \\
\hline \multirow{2}{*}{ National traditions } & 0.0668 & 0.0455 & 0.0492 \\
\cline { 2 - 4 } & $\mathrm{p}=0.347$ & $\mathrm{p}=0.522$ & $\mathrm{p}=0.489$ \\
\hline \multirow{2}{*}{ Family traditions } & 0.0065 & 0.0492 & 0.0180 \\
\cline { 2 - 4 } & $\mathrm{p}=0.928$ & $\mathrm{p}=0.489$ & $\mathrm{p}=0.801$ \\
\hline \multirow{2}{*}{ Parents } & 0.0067 & 0.1294 & 0.0661 \\
\cline { 2 - 4 } & $\mathrm{p}=0.925$ & $\mathrm{p}=0.068$ & $\mathrm{p}=0.353$ \\
\hline \multirow{2}{*}{ Uncle, grandfather, a family member } & 0.0430 & 0.0118 & 0.0434 \\
\cline { 2 - 4 } & $\mathrm{p}=0.545$ & $\mathrm{p}=0.868$ & $\mathrm{p}=0.542$ \\
\hline \multirow{2}{*}{ Religion, priest } & 0,1742 & 0.1316 & 0.0492 \\
\cline { 2 - 4 } & $\mathrm{p}=0.014$ & $\mathrm{p}=0.063$ & $\mathrm{p}=0.489$ \\
\hline \multirow{2}{*}{ I determine them myself } & 0.0448 & 0.1050 & 0.0500 \\
\cline { 2 - 4 } & $\mathrm{p}=0.529$ & $\mathrm{p}=0.139$ & $\mathrm{p}=0.482$ \\
\hline & 0,1565 & 0.1293 & 0.0068 \\
\cline { 2 - 4 } & $\mathrm{p}=0.027$ & $\mathrm{p}=0.068$ & $\mathrm{p}=0.924$ \\
\hline
\end{tabular}

Table 4. Analysis of the correlation between sources of knowledge about contemporary threats to national security and the independent variable (gender), taking into account the Pearson's coefficient

\section{Conclusions}

The objective of the study was to determine the opinions of students of military classes about the aspects of national security in Poland, with particular focus on social attitudes conducive to the strengthening of national security, factors shaping national identity, and threats to national security. Another objective of the study was a diagnosis of the knowledge of the respondents about national security. An analysis of the results made it possible to achieve the set objectives and to find answers to the research problems.

1. Students of military classes found the following attitudes to be conducive to the strengthening of national security: respect for national heritage, traditions, and national symbols (93\%), patriotism (93\%), national awareness (92\%), respect for law and customs (91\%), social activity (91\%), being raised in a family and respect for the family (90\%), and cooperation skills (99\%). The men found 
a sense of patriotism, national awareness, and social activity to be important, while being raised in a family and respect for the family were important to women.

2. In the opinion of students of military classes, national identity is shaped most of all by such factors as language (96\%), knowledge of history and national heritage (94\%), patriotic education (92\%), common symbols and respect for them (91\%), and cultivation of national traditions (90\%). Women much more often than men indicated that the factor that shapes national identity was the cultivation of national traditions.

3. In the opinion of students of military classes, the contemporary threats to national security are: international crime and terrorism (83\%), international armed conflicts (83\%), migrations of people (79\%), fights between states for domination and geopolitical changes (77\%), and the instability of alliances between states (76\%). Women significantly more often than men indicated that a threat to national security is the atheisation of Europe and a crisis of values.

4. The participating students get their knowledge about contemporary threats to national security from the Internet (68\%), their teachers/educators (51\%), books, press, radio, and television (49\%), other members of their classes (29\%), and their parents (29\%). Regardless of their gender, the primary source of their knowledge is the Internet. Men significantly more often than women determined the existing threats to national security on their own.

Due to the fact that education in military classes is more and more popular in Poland (cf. Kanarski, Koter, Loranty and Urych 2016, pp. 71-82), it is necessary to conduct systematic studies on the functioning of these classes, with particular focus on, among other things, the teaching and education process. There is also a need for support for the curricula of such classes from military institutions and units. It should be mentioned that the War Studies University in Warsaw 
supervises the educational process of students of selected uniformed classes insecondary schools teaching the subject of military education ${ }^{3}$. The results of the undertaken activities will be presented in the first quarter of 2019.

\section{References}

Glińska, P., 2017. MON ma program dla klas mundurowych. Polska Zbrojna, 11 May 2017, [27 Oct 2017] http://www.polska-zbrojna.pl/home/articleshow/22585?t=MON-maprogram-dla-klas-mundurowych

Jakubowska U., 1993. Czynności badawcze w psychologii i pedagogice. Zarys problematyki. Wydawnictwo Uczelniane WSP, Bydgoszcz.

Kanarski L., Koter M., Loranty K., and Urych I., 2016. Wstępna diagnoza funkcjonowania klas mundurowych - wyniki badań pilotażowych. In A. Skrabacz, I. Urych, L. Kanarski (eds), Klasy mundurowe. Od teorii do dobrych praktyk. Wydawnictwo Akademii Obrony Narodowej, Warsaw.

Kanarski,L.,Koter, M., and Urych, I., 2014. Wstęp do analizy funkcjonowania klas wojskowych po 1989 roku. In J. Walczak (ed.), Społeczny wymiar obronności. Stowarzyszenie Ruch Wspólnot Obronnych: MCOPY Paweł Żerański, Obryte; Warsaw.

Skrabacz, A., Urych, I. and Kanarski, L. (eds), 2016. Klasy mundurowe. Od teorii do dobrych praktyk. Wydawnictwo Akademii Obrony Narodowej, Warsaw.

Pilch T., Bauman T., 2001. Zasady badań pedagogicznych. Strategie ilościowe i jakościowe. Żak, Warsaw.

Program nauczania dla szkót ponadgimnazjalnych przedmiotu "Edukacja wojskowa", 2017. Warsaw.

Sztumski J., 1999. Wstęp do metod i technik badań społecznych. Katowice.

Urych I., 2016. Military class in Poland - experiences and perspectives. Security and Defence Quarterly, 2(11), 110-132.

3 In cooperation with the Ministry of National Education, on 4 September 2017, the Ministry of National Defence introduced a pilot programme related to military education in selected, certified 57 secondary schools in Poland that have uniformed classes. The programme mostly consists of three semesters of school education, starting from 4 September 2017 and ending approximately on 11 February 2019 - that start of the winter break in 2019. The military education programme covers a total of 185 hours of theoretical and practical classes, including field training - a training camp and 30 hours of own studies. The performance of the Programme for teaching the military education subject will take place with the support of military units (MU), training centres, and Field Military Administration Bodies suitable for the locations of the schools. The contents of the curricula in the Programme are patterned after the training programme of the Territorial Defence Forces and have been supplemented with elements of military preparatory service. Cf. Program nauczania dla szkół ponadgimnazjalnych przedmiotu "Edukacja wojskowa” 2017. 